\title{
Koncept STEM se zaměřením na problematiku Industry 4.0
}

\author{
Miroslav Malaga ${ }^{1}$, Zdeněk Ulrych ${ }^{1}$ \\ ${ }_{1}$ Západočeská univerzita v Plzni, Fakulta strojní, Katedra průmyslového inženýrství a \\ managementu \\ Univerzitní 8, Plzeň, 306 14, Česká republika \\ malaga@kpv.zcu.cz \\ ulrychz@kpv.zcu.cz
}

\begin{abstract}
Anotace: Technické vzdělání není, a ani nemůže být souborem samostatných znalostí a dovedností bez jakékoliv provázanosti. Více než $v$ jakémkoliv jiném typu vzdělání je u technického vzdělání, a zejména u multioborových zaměření typu průmyslových inženýrů, potřeba klást důraz na provázanost znalostí a dovedností a dosáhnout tak synergie. Dá se ř́ici, že toto platilo již dávno $v$ historii, kdy největší objevitelé a vynálezci měli znalosti nejen prưřezové v rámci jedné vědní kategorie, ale i napríič vědními disciplínami (přírodní vědy, technické vědy, filosofie, umění). $V$ době čtvrté průmyslové revoluce (Průmysl 4.0) toto začíná být opět aktuální, protože nejen takto vzdělaný člověk bude mít pro společnost vysokou hodnotu, ale také bude mít ty nejlepší možné předpoklady pro to, aby $v$ konkurenčním světě obstál.
\end{abstract}

\section{Koncept STEM}

Problém potřeby provázanosti znalostí by $v$ dnešní době měla řešit každá vzdělávací organizace, nebo instituce. $V$ rámci technického vzdělání je zajímavý koncept STEM, který vznikl v USA v 90. letech minulého století pro označení vzdělávání $v$ oborech prírodní vědy (Science), techniky (Technology), technologie (Engineering) a matematiky (Matematics) [1]. I $v$ dnešní době je koncept dále rozvíjen a rozšiřován na STEAM (A - arts, schopnost tvoriit, formulovat, prezentovat), STREAM ( $R$ - riting, zvládnutí jazyka vědy) či STEAMIE (IE - include everyone, tedy každý může být vzděláván) [2]. Řešeních postavených na konceptu STEM je na trhu velké množství, velmi rozšířený je např. vzdělávací jednodeskový počítač BBC Micro:Bit [3], RaspberryPi [4], Arduino [5], Edison robot [6], nebo komplexní stavebnice např. společností Lego [7], nebo Fischertechnik [8].

\subsection{STEM pro vzdělávání průmyslového inženýra}

$\checkmark$ rámci vzdělávání průmyslových inženýrů je potřeba provázat znalosti hlavně matematiky, mechaniky, konstruování, elektrotechniky a elektroniky, informatiky a programování, schopnosti odprezentovat a pochopitelně vysvětlit svou práci včetně jejich výsledků, a to vše doplnit kreativitou. To není v silách jednoho předmětu, jedné katedry ani jedné fakulty, ale je potřeba někde začít... Ve školním roce 2019/2020 bude do výuky na Katedře průmyslového inženýrství a managementu Západočeské univerzity v Plzni 
zavedena práce se stavebnicí Fishertechnik education - STEM Engineering. Hlavním cílem v tuto chvíli je poukázat na souvislosti a návaznosti jednotlivých částí studia a rozšiřit schopnosti algoritmizace, programování, analytického myšlení i představivosti v kontextu problematiky Industry 4.0.

\subsection{Fischertechnik education - STEM Engineering}

Jedná se o polytechnickou stavebnici umožňující stavbu kostry modelů ze stavebních bloků a mechanických součástí (včetně převodovek, ozubených kol apod.), výkonových součástí (elektromotory, ventily, kompresory, USB kamera, optický barevný senzor, světelné moduly...) a součástí pro sběr/vyhodnocení údajů (např. NTC rezistor pro měření teploty). Stavebnici Ize $v$ prípadě potřeby rozšírit o další mechanické i výkonové součástky. $\mathrm{K}$ oživení a rízzení modelů pak slouží programovatelná rídící jednotka a tvorba řídících programů primárně probíhá ve vývojovém prostředí ROBO Pro, kde se programuje vytvářením vývojových diagramů formou skládání programovacích bloků. $V$ prípadě potřeby lze programovat řídící kód i v jazyku C/C++ [9], nebo Pythonu [10].

Součástí stavebnice je i návod na stavbu modelů automatizovaného skladu, automatizovaného trí́dění výrobků, robotické ruky, AGV (automated guided vehicle - automaticky rrízené vozidlo) včetně rídících programů. Na obrázku 1 je ukázka automatizovaného skladu.

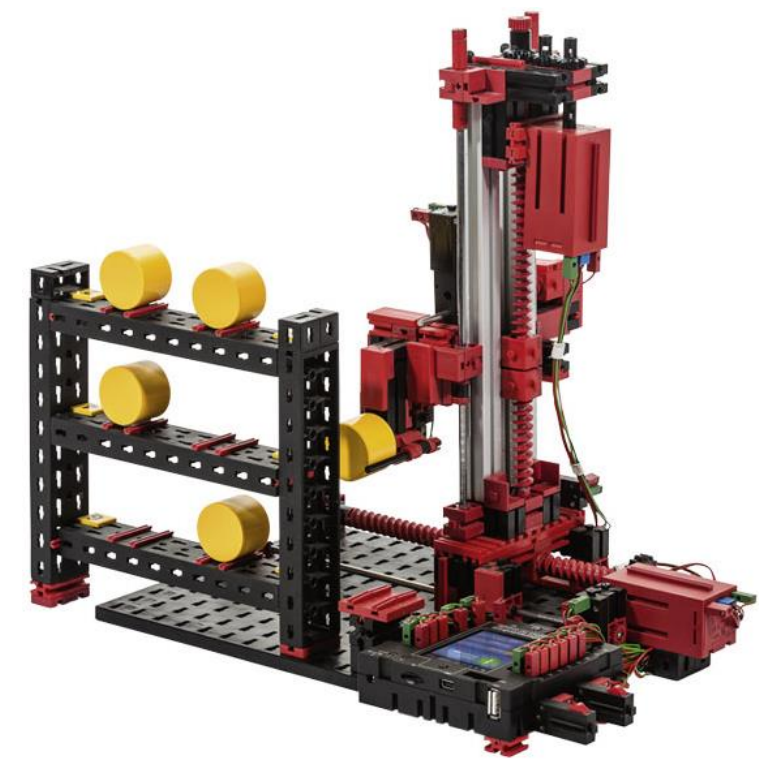

Obrázek 1 - Fischertechnic - automatizovaný sklad [11]

Výhodou do budoucna je schopnost komunikace mezi jednotlivými rídícími jednotkami, resp. modely přes standardy WIFI, nebo Bluetooth. Tím se otevírá možnost vytvářet např. modely automatizovaných výrobních hal a s možností stavby modelů a jejich komunikace mezi sebou s ohledem na trendy dnešní doby, tedy požadavky Industry 4.0. 


\subsection{Ukázka jednoduchého modelu včetně části rrídícího programu}

Jednoduchou ukázkou je např. poloautomatizovaný pojezd. Na obrázku 2 je vidět model, který se skládá z rí́dící jednotky, vodiče pojezdu vybaveného dvěma koncovými spínači a pojezdem skládajícího se z elektromotoru a převodovky. Výsledkem je tedy model a jeho řídící program, pomocí kterého se dává př́kaz pojezdu na jakou má přejet stranu a pojezd následně požadovaný pohyb vykoná.

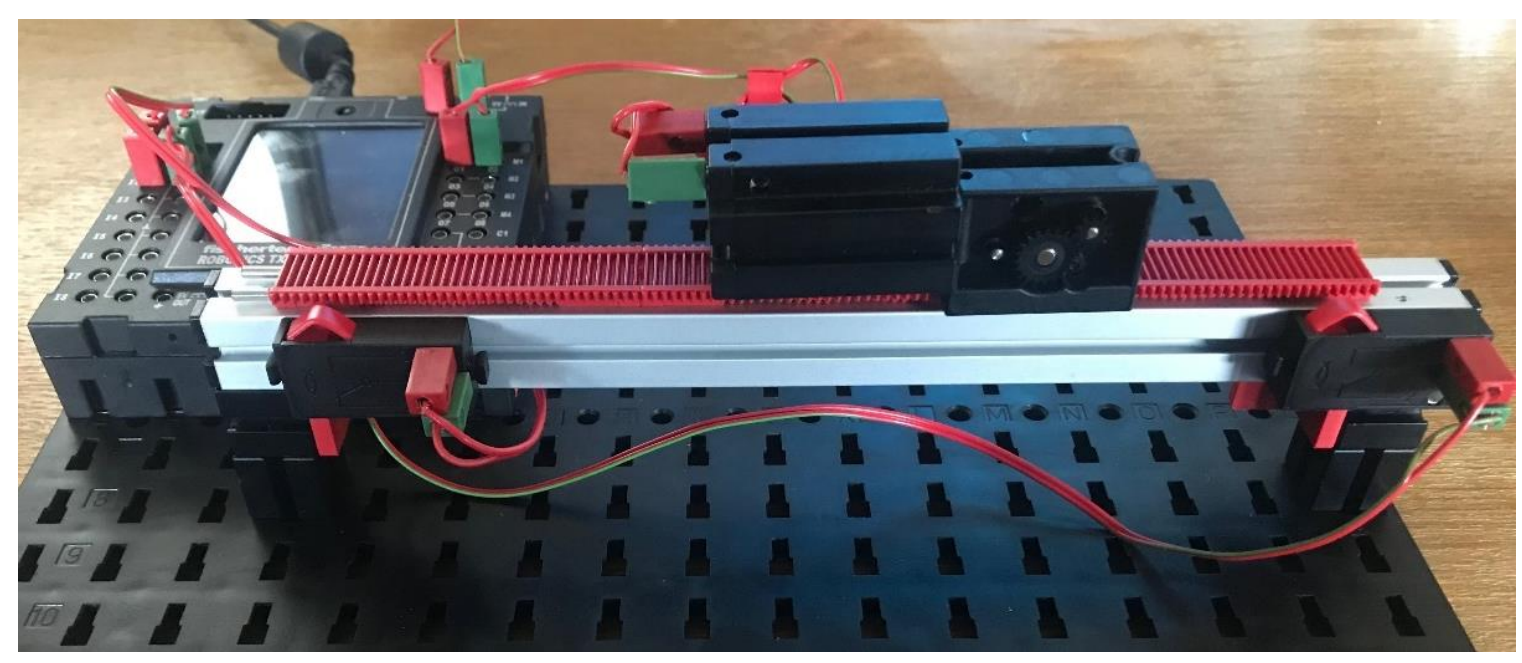

Obrázek 2 - Model poloautomatizovaného pojezdu

Z řídícího programu si ukažme alespoň část. $\mathrm{Na}$ obrázku 3 je vidět okomentovaný podprogram pro vyhodnocení lokace pojezdu. Tato informace je pak předávána do GUI pro ovládání pojezdu, kde se zobrazuje. 


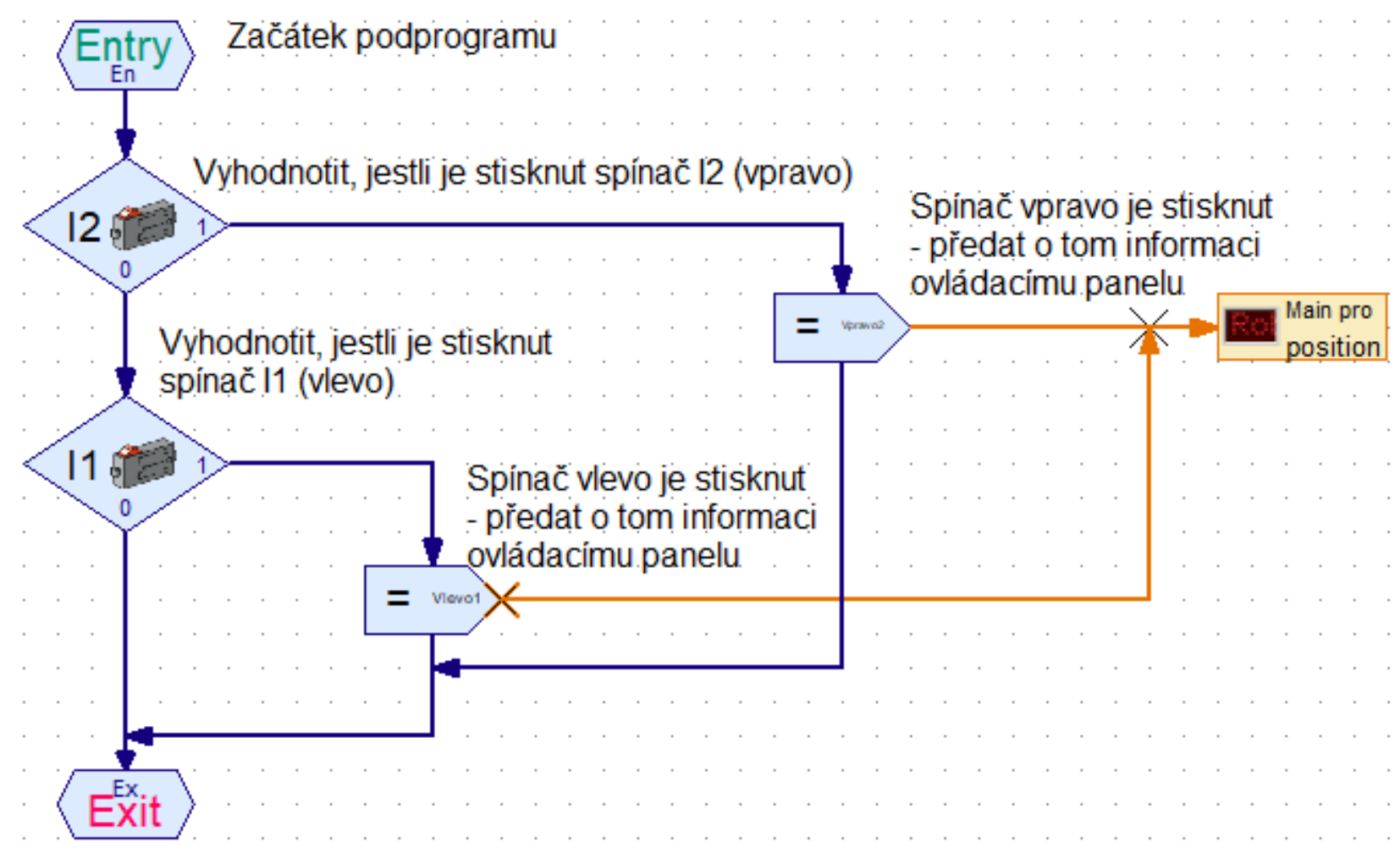

Obrázek 3 - Podprogram pro vyhodnocení lokace pojezdu

V rámci vývojového prostředí Ize pro rídící programy vytvářet GUI jak pro ovládání z počítače, tak i pro ovládání dotykem přes dotykovou obrazovku rídící jednotky. Výsledný model tedy může fungovat nezávisle na připojení $k$ počítači. Na obrázku 4 je vidět jednoduché GUI pro řizení modelu z počítače, které zobrazuje umístění pojezdu ( 0 - někde mezi pozicí 1 a 2, 1 - pozice vlevo, 2 - pozice vpravo) a ovládací tlačítka pro príkaz pojezdu „jed” vlevo“ a "jed' vpravo“.

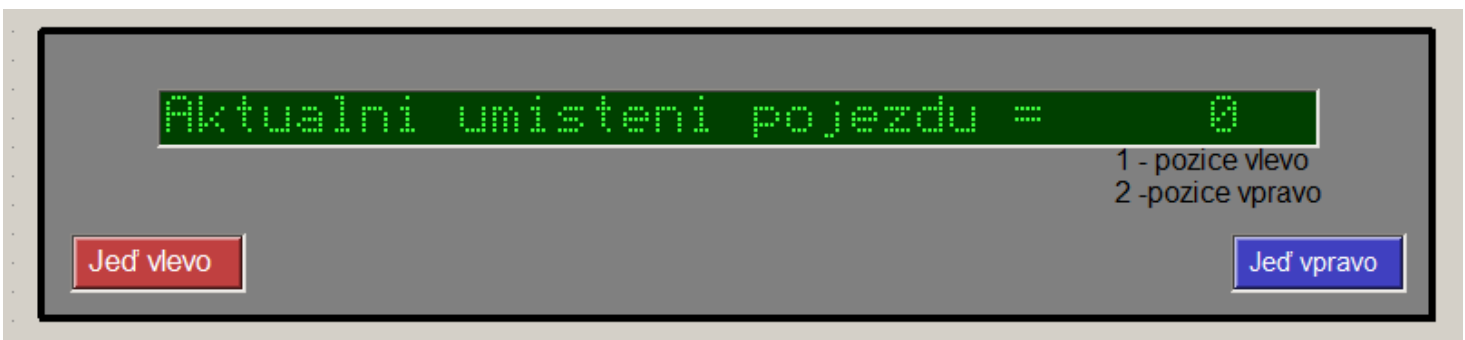

Obrázek 4 - GUI programu pro ovládání pojezdu

\section{STEM stavebnice a Industry $\mathbf{4 . 0}$}

$\checkmark$ rámci předchozího textu bylo řečeno, že jednotlivé řídící jednotky/modely stavebnice od Fischertechnik spolu mohou komunikovat. Naše katedra od léta navíc disponuje ještě od výrobce sestaveným cvičným modelem výrobní haly se zaměřením na Industry 4.0, nazvaným Training Factory Industry 4.0, který je na obrázku 5 . 


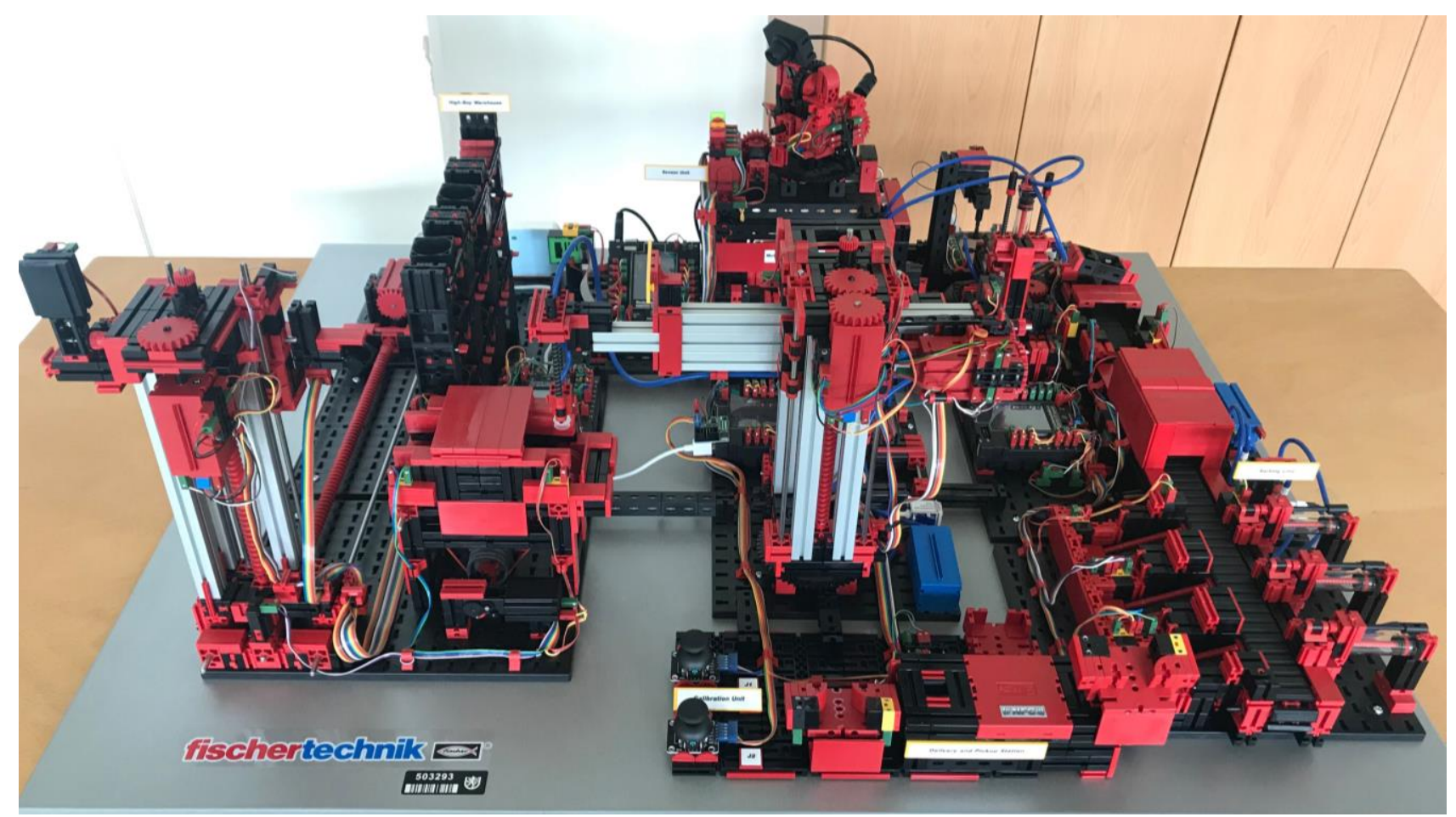

Obrázek 5 - Fischertechnik Training Factory Industry 4.0

Model se skládá z robotického otočného ramena s vakuovým systémem pro uchopení/upuštění materiálu a NFC čtečkou (Near Field communication, technologie umožňující bezdrátovou výměnu dat), automatizovaného skladu, obráběcího zařízení, dopravníku, sortovacího zařízení pracujícího na principu detekce barvy a senzoru prostředí (hlídání teploty, vlhkosti, tlaku a kvality vzduchu) s otočnou kamerou. Data ze simulace jsou ukládány do cloudu, kde je možné si je prohlížet a pracovat s nimi z pohledu dodavatele, výroby, nebo zákazníka.Na následujícím obrázku 6 je ukázka dashboardu pro pohled ze strany výroby, kde je vidět obsazení skladu, výrobní procesy, informace z NFC čtečky a stav továrny.

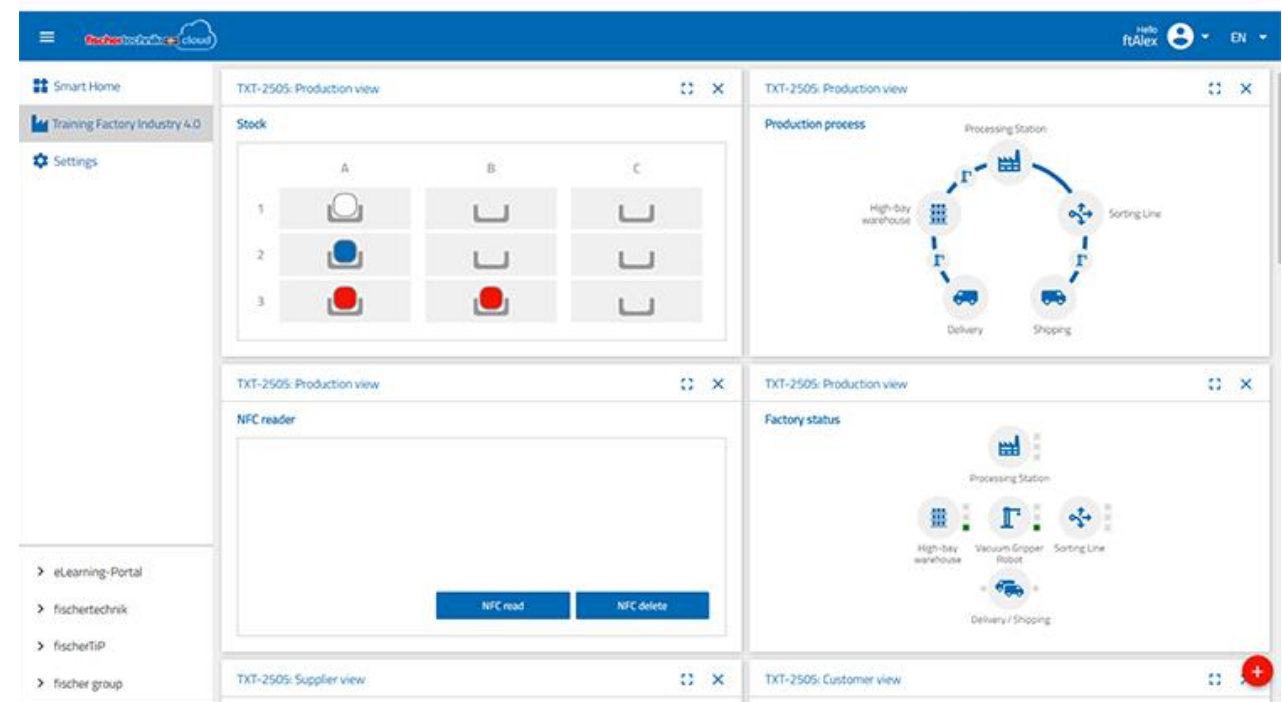

Obrázek 6-Dashboard Training Factory Industry 4.0 [12] 
Model je naprogramovaný $v$ jazyce $C$ a zdrojové kódy jsou dostupné na githubu [13]. Po důkladném seznámení s modelem a následně zdrojovými kódy je možné upravit si program podle vlastních potřeb.

\section{Využití stavebnicí STEM v praxi průmyslového inženýra}

Využití modelů (jak education stavebnic, tak modelu Training Factory Industry 4.0) je možné jak pro výuku studentů, kdy si vyzkouší proces výroby hned ze tři úhlů pohledu, tedy $z$ pohledu dodavatele (dodání materiálu), výroby (naskladnění materiálu, obrobení, vyskladnění materiálu), i zákazníka (nákup výrobku), tak pro pracovníky výrobních podniků, kterým je možné nasimulovat potřebné stavy/události a bez nepř́jemných faktických následků je připravit na jejich řešení ve skutečné praxi.

Stavebnice se jeví jako vhodná pro vytváření fyzických modelů a simulací (přinejmenším jejich zjednodušenou variantou), které mohou být zajímavým doplňkem např. diskrétní simulace a softwarové vizualizace. Modely a jejich fyzická tvorba včetně naprogramování mohou ukázat slabiny/zranitelnosti skutečného systému, který při vytvoření pouze diskrétní simulace, nebo vizualizace mohou zůstat nepovšimnuty.

Další neméně zajímavou možností je vytváření fyzických modelů (neodkazujících na konkrétní reálně existující systém) a k nim vytváření např. diskrétních simulací pro pochopení souvislostí mezi modelem a simulací.

\section{Závěr}

Princip STEM a stavebnice, které na jeho základu vznikly jsou nejen cestou, jak studentům umožnit vidět hmatatelné výsledky své práce napríklad ve fyzickém modelu automatizovaného skladu, který se chová podle studentem naprogramovaných pravidel, ale hlavně studenty naučí přemýšlet v potřebných souvislostech, systémově a s ohledem na okolí navrženého a oživeného systému. Průmyslový inženýr z praxe pak může používat tyto stavebnice/systémy nejen pro tvorbu fyzických modelů a simulací, ale i pro vytváření prvotních návrhů systémů, nebo návrhu řešení problémů reálných systémů. $V$ některých př́padech je možné projekty postavené na STEM stavebnicích, nebo systémech využít $v$ praxi jako součást/doplněk velkých systémů, např. pro sběr dat.

\section{Poděkování}

Tento článek byl vytvořen za podpory interního grantu Západočeské univerzity číslo projektu je SGS-2018-031 s názvem Optimalizace parametrů udržitelného výrobního systému. 


\section{Použitá literatura}

[1] Koncept STEM, Národní ústav pro vzdělávání [online]. Národní ústav pro vzdělávání, 2001 [cit. 28.08.2019]. Dostupné z: http://www.nuv.cz/pkap/koncept-stem

[2] What Is STEM? (And STEAM, and STREAM?) - Niche Blog [online]. Niche: Explore Schools, Companies, and Neighborhoods, 2019 [cit. 28.08.2019]. Dostupné z: https://www.niche.com/blog/stem-vs-steam-vs-stream/

[3] Micro:bit Educational Foundation | micro:bit [online]. Micro:bit Educational Foundation, 2019 [cit. 29.08.2019]. Dostupné z: https://microbit.org/

[4] Teach, Learn, and Make with Raspberry Pi - Raspberry Pi [online]. Teach, Learn, and Make with Raspberry Pi-Raspberry Pi, 2019 [cit. 29.08.2019] Dostupné z: https://www.raspberrypi.org/

[5] Arduino - Home. Arduino - Home [online]. Dostupné z: https://www.arduino.cc/

[6] Edison Programmable Robot - Ideal for school classroom education. [online]. Edison Programmable Robot - Ideal for school classroom education, 2019 [cit. 29.08.2019] Dostupné z: https://meetedison.com/

[7] STEM - Secondary school - LEGO® Education [online]. LEGO, 2019 [cit. 29.08.2019]. Dostupné z: https://education.lego.com/en-gb/secondary/intro/stem

[8] STEM Sets - fischertechnik [online]. [cit. 29.08.2019]. Dostupné z: https://www.fischertechnik.de/en/products/teaching/stem-sets

[9] fischertechnik GmbH - GitHub [online]. GitHub, 2019 [cit. 29.08.2019]. Dostupné z: https://github.com/fischertechnik

[10] fischertechnik TXT community firmware [online]. Dostupné z: https://cfw.ftcommunity.de/ftcommunity-TXT/en/programming/python/tutorial-1.html

[11] STEM Engineering - fischertechnik [online]. 2019 [cit. 28.08.2019]. Dostupné z: https://www.fischertechnik.de/en/products/teaching/stem-sets/519341-stemengineering

[12] Dashboard - fischertechnik [online]. 2019 [cit. 29.08.2019]. Dostupné z: https://www.fischertechnik.de/en/service/elearning/teaching/dashboard

[13] TxtSmartFactoryLib: Main Page [online]. GitHub, 2019 [cit. 29.08.2019]. Dostupné z: https://fischertechnik.github.io/txt training factory doc/html/index.html 